\title{
DETERMINAN KEJADIAN ISPA NON PNEUMONIA PADA ANAK BALITA DI KELURAHAN KEDUNG SARI KECAMATAN SUKAJADI KOTA PEKANBARU
}

\author{
Christine Vita Gloria Purba, Okta Safryanni, Al Hidayati, Zulmeliza Rasyid \\ STIKES Hang Tuah Pekanbaru, Jalan Mustafa Sari No. 05 Tangkerang Selatan \\ e-mail : christinevgp@gmail.com
}

\begin{abstract}
Non pneumonia Acute Respiratory Tract Infection (ARI) is a respiratory tract disease that is acute with a cough that does not show symptoms of increased respiratory frequency and does not indicate the pull of the lower chest wall inward. The incidence of non pneumonia ARI in children under five in Kedung Sari Village was recorded at $40.06 \%$. This study aims to determine the description and determinant of the incidence of non-pneumonia ARI in children under five in Kedung Sari Village, Sukajadi District, Pekanbaru City in 2019. This type of research is quantitative observational analytic with cross sectional design. The study population was all children under five who lived in Kedung Sari Village, Sukajadi District, Pekanbaru City, amounting to 312 people with a sample of 172 respondents. The sampling technique was done by consecutive sampling. The type of data used in this study are primary data and secondary data by means of retrieving data through measurements and questionnaires. Data analysis was done by univariate and bivariate with chi square test. The results showed that there was a correlation between exposure to cigarette smoke ( $p$-value 0,000) and the incidence of non-pneumonia ARI in children under five. It is expected that health workers, especially in the health promotion section of the community health center in implementing control and eradication programs of Acute Respiratory Tract Infection can provide health education, especially regarding the dangers of cigarette smoke for children under five and recommend smokers to smoke in special places so children under five are not exposed cigarettes.
\end{abstract}

Keywords: Non Pneumonia Acute Respiratory Tract Infection, Children Under Five

\section{Pendahuluan}

Infeksi Saluran Pernapasan Akut (ISPA) adalah penyakit saluran pernapasan yang besifat akut dengan berbagai macam gejala (sindrom) yang disebabkan oleh berbagai sebab (multifactorial) (Widoyono, 2011). Radang akut yang terjadi pada saluran pernapasan atas (hidung dan faring) maupun bawah (bronkus, bronkeolus, dan alveolus) di antaranya disebabkan oleh masuknya mikroorganisme (bakteri, virus, riketsia) ke dalam saluran pernapasan sehingga menimbulkan gejala penyakit yang dapat berlangsung sampai 14 hari (Hartono \& Rahmawati, 2012; Wijayaningsih, 2013). Gejala penyakit diawali dengan panas, disertai tenggorokan sakit atau nyeri telan, pilek, batuk kering atau berdahak (Kemenkes
RI, 2015). Batuk yang terjadi dapat disertai dengan pernapasan yang sulit atau cepat disertai tarikan dinding dada ke arah dalam saat bernapas (SDKI, 2017).

Hampir empat juta orang meninggal akibat ISPA setiap tahun, dimana sebanyak $98 \%$ disebabkan oleh infeksi saluran pernapasan bawah (WHO, 2007). Berdasarkan hasil Survei Demografi dan Kesehatan Indonesia (SDKI) tahun 2017, balita dengan gejala ISPA yang berobat ke fasilitas atau tenaga kesehatan tercatat sebanyak $92 \%$ dan bila dibandingkan dengan hasil SDKI tahun 2012 (75\%), angka ini menunjukkan peningkatan sebesar 17 persen. Periode prevalence ISPA di Indonesia berdasarkan diagnosis tenaga kesehatan dan keluhan penduduk menurut hasil utama Riset Kesehatan Dasar 
(Riskesdas) tahun 2018 tercatat sebesar $9,3 \%$.

Di Provinsi Riau proporsi kasus ISPA pada balita menunjukkan peningkatan dari tahun ke tahun. Berdasarkan klasifikasi kasus ISPA, kejadian batuk bukan pneumonia pada balita jauh lebih banyak dibandingkan kejadian pneumonia dan pneumonia berat, dengan proporsinya berturut-turut adalah 95,87\% (2013); 95,94\% (2014); 95,77\% (2015); dan $95,93 \%$ (2016). Walaupun ISPA non pneumonia tidak dilaporkan sebagai penyebab kematian balita, penyakit ini harus tetap diwaspadai karena berpotensi menjadi parah atau pneumonia. Selain itu, menurut perkiraan secara nasional $10 \%$ dari jumlah balita akan menderita pneumonia setiap tahunnya (Dinkes Provinsi Riau, 2017).

Berdasarkan data Laporan Program Pengendalian ISPA Dinas Kesehatan Kota Pekanbaru Tahun 2017, kejadian ISPA non pneumonia lebih banyak terjadi pada anak usia satu sampai dengan kurang dari lima tahun. Jumlah keseluruhan balita dengan kasus ISPA non pneumonia adalah 25.500 orang. Dari angka tersebut jumlah anak balita usia satu sampai dengan kurang dari lima tahun dengan ISPA non pneumonia tercatat sebesar 19.701 orang. Sedangkan untuk usia di bawah satu tahun berjumlah 5.799 orang.

Puskesmas Melur yang memiliki wilayah kerja di Kelurahan Harjosari, Kelurahan Kedung Sari, Kelurahan Sukajadi, dan Kelurahan Pulau Karam adalah salah satu puskesmas rawat jalan dalam wilayah Kecamatan Sukajadi yang termasuk ke dalam sepuluh besar puskesmas dengan kasus ISPA tertinggi (Dinas Kesehatan Kota Pekanbaru, 2017). Dari 10 besar penyakit di Puskesmas Melur tahun 2017, ISPA menempati urutan pertama dengan jumlah 3.084 kasus (Puskesmas Melur, 2017). Berdasarkan studi pendahuluan yang dilakukan terhadap Laporan Bulanan ISPA di Puskesmas Melur tahun 2018, proporsi kasus ISPA pada anak balita dengan pneumonia sebanyak $0,51 \%$ dan non pneumonia sebanyak $23,93 \%$.

Jika dilihat proporsi kasus ISPA non pneumonia lebih tinggi jika dibandingkan dengan kasus pneumonia. Selanjutnya proporsi kasus ISPA non pneumonia tertinggi pada anak balita terjadi di Kelurahan Kedung Sari yang tercatat sebesar 40,06\%. Proporsi kasus ISPA non pneumonia di kelurahan lainnya, seperti di Kelurahan Sukajadi sebesar 12,64\%, Kelurahan Harjo Sari sebesar 10,53\%, dan Kelurahan Pulau Karam sebesar $6,6 \%$.

\section{METODE}

Jenis penelitian yang digunakan adalah kuantitatif analitik observasional dengan desain cross sectional. Penelitian dilakukan di Kelurahan Kedung Sari Kecamatan Sukajadi Kota Pekanbaru pada bulan Februari 2019 dengan populasi seluruh anak balita yang bertempat tinggal di Kelurahan Kedung Sari Kecamatan Sukajadi. Jumlah sampel yang digunakan dalam penelitian ini sebanyak 172 responden dengan kriteria inklusi: ibu atau keluarga dekat anak balita di rumah bersedia menjadi responden, bertempat tinggal di Kelurahan Kedung Sari Kecamatan Sukajadi, anak balita dengan usia $1-4$ tahun, dan apabila responden mempunyai lebih dari seorang anak balita di rumah, maka yang diambil adalah salah seorang dari mereka.

Adapun yang menjadi kriteria eksklusi adalah: ibu atau keluarga dekat anak balita di rumah tidak dapat berkomunikasi dengan baik, responden tidak berada di rumah, dan anak balita yang didiagnosis alergi oleh dokter. Pengambilan sampel dilakukan dengan teknik consecutive sampling yaitu cara pengambilan sampel yang dilakukan dengan memilih sampel yang memenuhi kriteria penelitian sampai kurun waktu tertentu sehingga jumlah sampel terpenuhi. Dalam proses pengambilan sampel peneliti terlebih dahulu menemui masing-masing 


\begin{tabular}{|c|c|c}
\hline JURNAL PENELITIAN KESMASY & VOL. 1 NO. 2 & EDITION: NOVEMBER 2018 - \\
\hline & http://ejournal.delihusada.ac.id/index.php/JPKSY & \\
\cline { 2 - 3 } RECEIVED: 17 FEBRUARI 2019 & REVISED: 18 MARET 2019 & ACCEPTED: 28 APRIL 2019 \\
\hline
\end{tabular}

Ketua RW dan Ketua RT setempat. Kemudian dari Ketua RT peneliti mendapat petunjuk untuk mengunjungi rumah-rumah responden yang sesuai dengan kriteria inklusi dari penelitian.

Variabel independen dalam penelitian terdiri dari perilaku ibu, paparan asap rokok, kepadatan hunian, dan status gizi. Sedangkan variabel dependennya adalah ISPA non pneumonia. Jenis data yang digunakan dalam penelitian terdiri dari data primer dan data sekunder. Data mengenai perilaku ibu, paparan asap rokok, dan umur anak balita dikumpulkan melalui teknik wawancara dengan menggunakan kuesioner serta data status gizi dan kepadatan hunian dilakukan pengukuran dengan menggunakan meteran dan timbangan berat badan. Data sekunder diperoleh dari Puskesmas Melur Pekanbaru.

Pengolahan data dilakukan melalui tahap editing, coding, processing, dan cleaning. Analisis data dilakukan dengan menggunakan analisis univariat dan analisis bivariate dengan uji chi square.

\section{HASIL DAN PEMBAHASAN}

\section{Analisis Univariat}

Berdasarkan Tabel 1 pada hasil analisis univariat diperoleh dari 172 responden, yang mengalami kejadian ISPA non pneumonia sebanyak 113 orang $(65,7 \%)$, ibu dengan perilaku kurang baik sebanyak 89 responden
$(51,7 \%)$, responden dengan adanya paparan asap rokok sebanyak 105 orang (61\%), responden dengan dengan kepadatan hunian yang tidak memenuhi syarat sebanyak 28 orang $(16,3 \%)$, dan responden dengan status gizi kurang sebanyak 35 orang (20,3\%).

Tabel 1. Hasil Analisis Univariat

\begin{tabular}{|c|c|c|c|}
\hline Variabel & Kategori & $\mathbf{n}$ & $\begin{array}{c}(\% \\
)\end{array}$ \\
\hline \multirow{2}{*}{$\begin{array}{l}\text { Kejadian } \\
\text { ISPA non } \\
\text { pneumonia }\end{array}$} & Iya & 113 & 65,7 \\
\hline & Tidak & 59 & 34,3 \\
\hline \multicolumn{2}{|l|}{ Jumlah } & 172 & 100 \\
\hline \multirow[t]{2}{*}{ Perilaku ibu } & $\begin{array}{l}\text { Kurang } \\
\text { baik }\end{array}$ & 89 & 51,7 \\
\hline & Baik & 83 & 48,3 \\
\hline Jumlah & & 172 & 100 \\
\hline \multirow{2}{*}{$\begin{array}{l}\text { Paparan } \\
\text { asap rokok }\end{array}$} & $\begin{array}{l}\text { Ada } \\
\text { paparan }\end{array}$ & 105 & 61 \\
\hline & $\begin{array}{l}\text { Tidak ada } \\
\text { paparan }\end{array}$ & 67 & 39 \\
\hline \multicolumn{2}{|l|}{ Jumlah } & 172 & 100 \\
\hline \multirow{2}{*}{$\begin{array}{l}\text { Kepadatan } \\
\text { hunian }\end{array}$} & $\begin{array}{l}\text { Tidak } \\
\text { memenuhi } \\
\text { syarat }\end{array}$ & 28 & 16,3 \\
\hline & $\begin{array}{l}\text { Memenuhi } \\
\text { syarat }\end{array}$ & 144 & 83,7 \\
\hline \multicolumn{2}{|l|}{ Jumlah } & 172 & 100 \\
\hline \multirow[t]{2}{*}{ Status gizi } & $\begin{array}{l}\text { Gizi } \\
\text { kurang }\end{array}$ & 35 & 20,3 \\
\hline & Gizi baik & 137 & 79,7 \\
\hline Jumlah & & 172 & 100 \\
\hline
\end{tabular}

Tabel 2. Hasil Analisis Bivariat

\begin{tabular}{|c|c|c|c|c|c|c|c|c|}
\hline \multirow{3}{*}{ Variabel } & \multicolumn{4}{|c|}{$\begin{array}{l}\text { Kejadian ISPA Non } \\
\text { Pneumonia }\end{array}$} & \multirow{2}{*}{\multicolumn{2}{|c|}{ Total }} & \multirow{3}{*}{$\begin{array}{c}\text { P } \\
\text { value }\end{array}$} & \multirow{3}{*}{$\begin{array}{c}\text { POR } \\
(95 \% \mathrm{CI})\end{array}$} \\
\hline & \multicolumn{2}{|c|}{ Ya } & \multicolumn{2}{|c|}{ Tidak } & & & & \\
\hline & $\mathbf{n}$ & $\%$ & $\mathbf{n}$ & $\%$ & $\mathbf{n}$ & $\%$ & & \\
\hline \multicolumn{9}{|l|}{ Perilaku Ibu } \\
\hline Kurang baik & 55 & 61,8 & 34 & 38,2 & 89 & 100 & \multirow{3}{*}{0,340} & 0,697 \\
\hline Baik & 58 & 69,9 & 25 & 30,1 & 83 & 100 & & $(0,370-1,315)$ \\
\hline Total & 113 & 65,7 & 59 & 34,3 & 172 & 100 & & \\
\hline
\end{tabular}




\begin{tabular}{|c|c|c|c|c|c|c|c|c|}
\hline \multicolumn{3}{|c|}{ JURNAL PENELITIAN KESMASY } & \multicolumn{5}{|c|}{ VOL. 1 NO. 2} & EDITION: NOVEMBER 2018 - \\
\hline \multirow{2}{*}{\multicolumn{3}{|c|}{ RECEIVED: 17 FEBRUARI 2019}} & \multicolumn{5}{|c|}{ http://ejournal.delihusada.ac.id/index.php/JPKSY } & \multirow[b]{2}{*}{ ACCEPTED: 28 APRIL 2019} \\
\hline & & & & REVIS & D: $18 \mathrm{M}$ & RET 2019 & & \\
\hline \multirow{3}{*}{ Variabel } & \multicolumn{4}{|c|}{$\begin{array}{c}\text { Kejadian ISPA Non } \\
\text { Pneumonia }\end{array}$} & \multirow{2}{*}{\multicolumn{2}{|c|}{ Total }} & \multirow{3}{*}{$\begin{array}{l}\mathrm{P} \\
\text { value }\end{array}$} & \multirow{3}{*}{$\begin{array}{c}\text { POR } \\
(95 \% \mathrm{CI})\end{array}$} \\
\hline & \multicolumn{2}{|c|}{ Ya } & \multicolumn{2}{|c|}{ Tidak } & & & & \\
\hline & $\mathbf{n}$ & $\%$ & $\mathbf{n}$ & $\%$ & $\mathbf{n}$ & $\%$ & & \\
\hline \multicolumn{7}{|l|}{$\begin{array}{l}\text { Paparan } \\
\text { Asap Rokok }\end{array}$} & \multirow{4}{*}{0,000} & \multirow{4}{*}{$\begin{array}{c}4,140 \\
(2,126-8,064)\end{array}$} \\
\hline Ada paparan & 82 & 78,1 & 23 & 21,9 & 105 & 100 & & \\
\hline $\begin{array}{l}\text { Tidak ada } \\
\text { paparan }\end{array}$ & 31 & 46,3 & 36 & 53,7 & 67 & 100 & & \\
\hline Total & 113 & 65,7 & 59 & 34,3 & 172 & 100 & & \\
\hline \multirow{2}{*}{\multicolumn{7}{|c|}{$\begin{array}{l}\text { Kepadatan } \\
\text { Hunian }\end{array}$}} & \multirow{5}{*}{0,360} & \multirow{5}{*}{$\begin{array}{c}1,696 \\
(0,675-4,257)\end{array}$} \\
\hline & & & & & & & & \\
\hline $\begin{array}{l}\text { Tidak } \\
\text { memenuhi } \\
\text { syarat }\end{array}$ & 21 & 75 & 7 & 25 & 28 & 100 & & \\
\hline Memenuhi & 92 & 63,9 & 52 & 36,1 & 144 & 100 & & \\
\hline $\begin{array}{l}\text { syarat } \\
\text { Total }\end{array}$ & 113 & 65,7 & 59 & 34,3 & 172 & 100 & & \\
\hline \multicolumn{7}{|l|}{ Status Gizi } & \multirow{4}{*}{0,551} & \multirow{4}{*}{$\begin{array}{c}0,734 \\
(0,342-1,576)\end{array}$} \\
\hline Gizi kurang & 21 & 60 & 14 & 40 & 35 & 100 & & \\
\hline Gizi baik & 92 & 67,2 & 45 & 32,8 & 137 & 100 & & \\
\hline Total & 113 & 65,7 & 59 & 34,3 & 172 & 100 & & \\
\hline
\end{tabular}

\section{Analisis Bivariat}

Dari hasil analisis bivariat pada Tabel 2 didapatkan variabel yang berhubungan secara signifikan yaitu paparan asap rokok ( $p$ value $=0,000)$ dan variabel yang tidak berhubungan yaitu perilaku ibu ( $p$ value $=$ $0,340)$, kepadatan hunian ( $p$ value $=0,360$ ), dan status gizi ( $p$ value $=0,551)$.

\section{PEMBAHASAN}

\section{Perilaku Ibu}

Tidak ada hubungan yang bermakna antara perilaku ibu dengan kejadian ISPA non pneumonia pada anak balita. Hasil uji Chi Square pada $a=0,05$ didapatkan nilai $p$ value 0,340 .

Setiap individu sejak lahir terkait di dalam suatu kelompok, terutama kelompok keluarga. Dalam keterkaitannya dengan kelompok ini membuka kemungkinan untuk dipengaruhi dan mempengaruhi anggotaanggota kelompok lain. Perilaku orang tua di samping berpengaruh terhadap kesehatan sendiri, juga berpengaruh terhadap anakanaknya.

Perilaku dalam pencegahan dan penanggulangan penyakit ISPA pada balita dapat dilakukan di keluarga oleh ibu ataupun anggota keluarga lainnya. Keluarga merupakan unit terkecil dari masyarakat yang berkumpul dan tinggal dalam satu rumah tangga, satu dengan lainnya saling tergantung dan berinteraksi. Bila salah satu atau beberapa anggota keluarga mempunyai masalah kesehatan, maka akan berpengaruh terhadap anggota keluarga lainnya. Peran aktif keluarga dalam menangani ISPA sangat penting karena penyakit ISPA merupakan penyakit yang ada sehari-hari di dalam masyarakat atau keluarga (Maryunani, 2010; Kholid, 2014; Syahdrajat, 2015).

Hasil penelitian ini tidak sejalan dengan penelitian yang dilakukan oleh Susanti, Arifin, dan Hayati (2018) yang mengatakan bahwa ibu yang melakukan perilaku berisiko menyebabkan balita sering terkena ISPA non pneumonia. Perilaku pencegahan ISPA yang 
http://ejournal.delihusada.ac.id/index.php/JPKSY

RECEIVED: 17 FEBRUARI 2019

REVISED: 18 MARET 2019

ACCEPTED: 28 APRIL 2019

telah dilakukan sedemikian rupa tidak menutup kemungkinan untuk menyebabkan anak balitanya tetap terkena ISPA non pneumonia.

Hal ini dapat disebabkan oleh faktor lainnya seperti paparan asap rokok yang berasal dari anggota keluarga yang merokok di dalam rumah. Asap rokok yang dihasilkan oleh anggota keluarga yang merokok tersebut menyebar ke seluruh penjuru ruangan di dalam rumah. Paparan asap rokok yang berada di dalam ruangan rumah akan menyebabkan balita terpapar asap rokok. Kebiasaan anak balita selalu bermain di dalam rumah bersama dengan ibunya sehingga apabila hal ini terjadi terus menerus maka lama kelamaan paparan asap rokok tersebut dapat menyebabkan gangguan pernapasan pada anak balita.

\section{Paparan Asap Rokok}

Ada hubungan yang bermakna antara paparan asap rokok dengan kejadian ISPA non pneumonia pada anak balita, responden yang memiliki paparan asap rokok berisiko 4,1 kali untuk terjadi ISPA non pneumonia pada anak balitanya dibandingkan dengan yang tidak memiliki paparan asap rokok.

Paparan asap rokok mengandung kurang lebih 4000 bahan kimia dimana 200 di antaranya beracun. Beberapa zat yang sangat berbahaya yaitu tar, nikotin, dan karbon monoksida. Asap rokok yang baru mati di asbak mengandung 50 kali pengiritasi pernapasan. Semakin pendek rokok semakin tinggi kadar racun yang siap melayang ke udara.

Asap rokok yang mengganggu kesehatan terdiri dari dua macam yaitu asap utama (mainstream) yang merupakan asap yang dihisap oleh si perokok dan asap sampingan (sidestream) yang merupakan asap yang berasal dari pembakaran ujung rokok yang kemudian menyebar ke udara. Asap sampingan memiliki konsentrasi yang lebih tinggi, karena tidak melalui proses penyaringan yang cukup. Pengisap asap sampingan memiliki risiko yang lebih tinggi untuk menderita gangguan kesehatan di antaranya gangguan pernapasan (Jaya, 2009).

Hasil penelitian ini sejalan dengan penelitian yang dilakukan oleh Jalil, Yasnani, dan Sety (2018) yang mengatakan bahwa ada hubungan paparan asap rokok dengan kejadian ISPA pada balita di wilayah kerja Puskesmas Kabangka dengan $p$-value = 0,014 . Selain itu, penelitian Wardani, Winarsih, dan Sukini (2016) juga mendukung bahwa ada hubungan yang bermakna antara paparan asap rokok dengan kejadian ISPA pada balita ( $p$-value $=0,007)$.

Anak balita yang sering berinteraksi dengan orang yang sedang merokok baik di dalam atau pun di luar ruangan berisiko untuk terpapar asap rokok. Interaksi yang berlangsung terus menerus menyebabkan kandungan dari asap sampingan yang dihisap oleh anak balita lama kelamanan menumpuk dan menempel di jalan napasnya sehingga menimbulkan penyakit ISPA non pneumonia.

\section{Kepadatan Hunian}

Tidak ada hubungan yang bermakna antara kepadatan hunian dengan kejadian ISPA non pneumonia pada anak balita. Hasil uji Chi Square pada $a=0,05$ didapatkan nilai $p$ value 0,360 . Namun berdasarkan nilai POR = 1,696 (95\% CI: 0,675-4,257) menunjukkan bahwa kepadatan hunian yang tidak memenuhi syarat memiliki risiko sebesar 1,7 kali untuk menyebabkan terjadinya ISPA non pneumonia pada anak balita dibandingkan dengan kepadatan hunian yang memenuhi syarat.

Berdasarkan Keputusan Menteri Kesehatan Republik Indonesia Nomor 829/MENKES/VII/1999 dijelaskan bahwa salah satu persyaratan kesehatan rumah tinggal adalah luas ruang tidur minimal 8 meter dan tidak dianjurkan digunakan lebih 
dari 2 orang tidur dalam satu ruang tidur. Kepadatan penghuni dalam satu rumah tinggal akan memberikan pengaruh bagi penghuninya. Hal ini tidak sehat karena di samping menyebabkan kurangnya oksigen, juga bila salah satu anggota keluarga terkena penyakit infeksi, terutama ISPA akan mudah tertular kepada anggota keluarga lainnya (Qiyam et al., 2016).

Hasil penelitian ini sejalan dengan Nahabila, Lapau, dan Herniwanti (2018) yang mengatakan bahwa tidak ada hubungan kepadatan hunian dengan kejadian ISPA non pneumonia pada anak balita di Wilayah Kerja Puskesmas Harapan Raya Kota Pekanbaru dengan $p$-value $=0,797$. Selain itu, penelitian ini juga sejalan dengan Ningrum (2015) yang mengatakan bahwa tidak terdapat hubungan kepadatan hunian dengan kejadian ISPA non pneumonia pada balita $(p$-value $=0,281)$.

Terkait hasil penelitian ini kemungkinan dapat disebabkan oleh kebiasaan responden yang tidur di ruang tamu. Sementara ruang tamu memiliki luas lantai lebih memadai dibandingkan luas ruang tidur. Luas ruangan yang memadai dan disertai ventilasi dapat melancarkan sirkulasi udara sehingga memungkinkan diperolehnya kadar oksigen yang optimum bagi pernapasan. Hal ini kemungkinan menjadi penyebab tidak mudahnya terserang penyakit.

\section{Status Gizi}

Tidak ada hubungan yang bermakna antara status gizi dengan kejadian ISPA non pneumonia pada anak balita. Hasil uji Chi Square pada $a=0,05$ didapatkan nilai $p$ value 0,551 .

Dalam keadaan gizi yang baik, tubuh mempunyai cukup kemampuan untuk mempertahankan diri terhadap penyakit infeksi. Jika keadaan gizi menjadi buruk maka reaksi kekebalan tubuh akan menurun yang berarti kemampuan tubuh mempertahankan diri terhadap serangan infeksi menjadi turun. Balita dengan gizi yang kurang akan lebih mudah terserang ISPA dibandingkan balita dengan gizi normal karena faktor daya tahan tubuh yang kurang. Penyakit infeksi sendiri akan menyebabkan balita tidak mempunyai nafsu makan dan mengakibatkan kekurangan gizi. Pada keadaan gizi kurang, balita lebih mudah terserang ISPA berat bahkan serangannya lebih lama. (Notoatmodjo, 2007; Maryunani, 2010).

Hasil penelitian ini sejalan dengan penelitian yang dilakukan oleh Darsono, Widya, dan Suwarni (2018) bahwa tidak ada hubungan status gizi dengan kejadian ISPA pada balita dengan $p$-value $=0,554$. Begitu pula dengan penelitian Felita, Kurniawan, dan Dewajanti (2016) yang mengatakan bahwa tidak terdapat hubungan status gizi dengan kejadian ISPA pada balita ( $p$-value $=0,754)$.

Status gizi yang baik memungkinkan anak balita juga bisa terserang penyakit. Hal ini kemungkinan dapat disebabkan oleh faktor kelengkapan imunisasi yang diperoleh anak selama hidupnya. Imunisasi yang lengkap dapat mempengaruhi daya tahan tubuhnya sehingga dapat menyebabkan anak tidak rentan terjangkit penyakit infeksi demikian pula sebaliknya imunisasi yang tidak lengkap memudahkan tubuh anak terserang penyakit.

\section{KESIMPULAN}

Proporsi kejadian ISPA non pneumonia pada anak balita di Kelurahan Kedung Sari Kecamatan Sukajadi Kota Pekanbaru Tahun 2019 adalah sebesar 65,7\% sedangkan yang tidak mengalami kejadian ISPA non pneumonia sebesar 34,3\%. Variabel yang berhubungan dengan Kejadian ISPA non pneumonia di Kelurahan Kedung Sari Kecamatan Sukajadi Kota Pekanbaru Tahun 2019 adalah paparan asap rokok sedangkan variabel-variabel yang tidak berhubungan adalah perilaku ibu, kepadatan hunian, dan status gizi. 


\begin{tabular}{l|c|c}
\hline JURNAL PENELITIAN KESMASY & VOL. 1 NO. 2 & EDITION: NOVEMBER 2018 - \\
\hline & http://ejournal.delihusada.ac.id/index.php/JPKSY & \\
\cline { 2 - 3 } RECEIVED: 17 FEBRUARI 2019 & REVISED: 18 MARET 2019 & ACCEPTED: 28 APRIL 2019 \\
\hline
\end{tabular}

\section{SARAN}

Diharapkan kepada tenaga kesehatan khususnya pada bagian promosi kesehatan di puskesmas terkait dalam pelaksanaan program pengendalian dan pemberantasan ISPA dapat memberikan pendidikan kesehatan terutama mengenai bahaya asap rokok bagi anak balita dan merekomendasikan kepada para perokok agar dapat merokok di tempat-tempat khusus sehingga balita tidak terpapar asap rokok.

\section{DAFTAR PUSTAKA}

Darsono, P.V., Widya, N., \& Suwarni. (2018, Juli). Faktor-faktor yang Berhubungan dengan Kejadian ISPA pada Balita di Puskesmas Binuang. Dinamika Kesehatan, 9 (1) 622. Februari 20, 2019. https://ojs.dinamikakesehatan.unism .ac.id/index.php/dksm/article/view/3 09

Dinkes Provinsi Riau. (2017). Profil Kesehatan Provinsi Riau 2016. Dinkes Provinsi Riau.

Dinkes Kota Pekanbaru. (2018). Profil Kesehatan Kota Pekanbaru Tahun 2017. Dinkes Kota Pekanbaru.

Felita, P., Kurniawan, H., \& Dewajanti, A.M. (2018, Januari-Maret). Hubungan Status Gizi dengan Kejadian infeksi Saluran Pernapasan Akut pada Balita di Puskesmas Kecamatan Kebon Jeruk Bulan Agustus 2016. Jurnal Kedokteran Meditek. 24 (65). Februari 19, 2019. http://ejournal.ukrida.ac.id/ojs/index .php/Ked/article/view/1655

Hartono, R. \& Rahmawati, D. (2012). Gangguan Pernapasan pada Anak: ISPA. Yogyakarta: Nuha Medika.

Jalil, R., Yasnani, \& Sety, L.O.M. (2018, Desember). Faktor-faktor yang Berhubungan dengan Kejadian ISPA pada Balita di Wilayah Kerja Puskesmas Kabangka Kecamatan Kabangka Kabupaten Muna Tahun 2018. Jimkesmas : Jurnal IImiah
Mahasiswa Kesehatan Masyarakat, 3 (4), 5-7. Februari 07, 2019. http://ojs.uho.ac.id/index.php/JIMKE SMAS/article/download/5478/4071

Jaya, M. (2009). Pembunuh Berbahaya Itu Bernama Rokok. Yogyakarta: Riz'ma.

Kementerian Kesehatan RI. (2015). Infodatin: Situasi Kesehatan Anak Balita di Indonesia. Pusat Data dan Informasi Kementerian Kesehatan RI.

Keputusan Menteri Kesehatan Republik Indonesia Nomor 829/MENKES/VII/1999. Menteri Kesehatan RI.

Kholid, A. (2014). Promosi Kesehatan: Dengan Pendekatan Teori Perilaku, Media, dan Aplikasinya untuk Mahasiswa dan Praktisi Kesehatan. Jakarta: Rajawali Pers.

Maryunani, A. (2010). I/mu Kesehatan Anak dalam Kebidanan. Jakarta: TIM.

Nahabila, T. Sy. R., Lapau B., \& Herniwanti. (2018, Oktober). Faktor Risiko Kejadian ISPA non Pneumonia pada Anak Balita di Wilayah Kerja Puskesmas Harapan Raya Kota Pekanbaru. Jurnal Photon, 9 (1), 21. Desember 11, 2018. http://ejurnal.umri.ac.id/index.php/p hoton/article/view/1053

Notoatmodjo, S. (2007). Kesehatan Masyarakat: IImu dan Seni. Jakarta: Rineka Cipta.

Puskesmas Melur. (2018). Profil Puskesmas Melur 2017. UPTD Puskesmas Melur.

Qiyam, N., et al. (2016). Tingkat Pengetahuan Ibu terhadap Penyakit ISPA (Infeksi Saluran Pernapasan Akut) pada Balita di Puskesmas Paruga Kota Bima Tahun 2016. Jurnal Ilmiah Ibnu Sina, 1 (2), 235247.

Riskesdas 2018. Hasil Utama Riskesdas 2018. Kemenkes RI : Badan Penelitian dan Pengembangan Kesehatan. 


\begin{tabular}{c|c|c}
\hline JURNAL PENELITIAN KESMASY & VOL. 1 NO. 2 & EDITION: NOVEMBER 2018 - \\
\hline & http://ejournal.delihusada.ac.id/index.php/JPKSY & \\
\cline { 2 - 3 } RECEIVED: 17 FEBRUARI 2019 & REVISED: 18 MARET 2019 & ACCEPTED: 28 APRIL 2019 \\
\hline
\end{tabular}

Survei Demografi dan Kesehatan Indonesia 2017. Jakarta : BKKBN, BPS, Kemenkes.

Susanti, L., Arifin, S., \& Hayati, L. (2018, Agustus). Hubungan Perilaku Berisiko Ibu dengan Frekuensi Infeksi Saluran Pernapasan Akut Non Pneumonia pada Balita. Homeostasis : Jurnal Tugas Akhir Mahasiswa Pendidikan Dokter, 1 (2), 590. Januari 14, 2019. http://jtam.ulm.ac.id/index.php/hom eostasis/article/view/698

Syahdrajat, T. (2015). Panduan Menulis Tugas Akhir Kedokteran dan Kesehatan Edisi Pertama. Jakarta: Kencana.

Wardani, N.K., Winarsih, S., \& Sukini, T. (2016, April). Hubungan antara Paparan Asap Rokok dengan Kejadian Infeksi Saluran Pernapasan Akut (ISPA) pada Balita di Desa Pucung Rejo Kabupaten Magelang Tahun 2014. Jurnal Kebidanan, 5 (10), 32. Januari 05, 2019. http://ejournal.poltekkessmg.ac.id/ojs/index.php/jurkeb/articl e/view/396

WHO. (2007). Pencegahan dan Pengendalian Infeksi Saluran Pernapasan Akut (ISPA) yang Cenderung Menjadi Epidemi dan Pandemi di Fasilitas Pelayanan Kesehatan. Pedoman Interim WHO. World Health Organization. Dalam https://www.who.int/csr/resources/p ublications/WHO CDS EPR 2007 8b ahasa.pdf. Diakses tanggal 26 Desember 2018.

Widoyono. (2011). Penyakit Tropis: Epidemiologi, Penularan, Pencegahan, dan Pemberantasannya. Jakarta: Erlangga.

Wijayaningsih, K.S. (2013). Asuhan Keperawatan Anak. Jakarta: Trans InfoMedia. 